\title{
Re: Re: Did King Herod suffer from a rheumatic disease? doi: $10.1007 / \mathrm{s} 10067-017-3583-\mathrm{Z}$
}

\author{
Cianna Leatherwood $^{1,2} \cdot$ Richard S. Panush ${ }^{3}$
}

Published online: 22 July 2017

(C) International League of Associations for Rheumatology (ILAR) 2017

Dear Dr. Grove,

Thank you for your thoughtful comments about our essay on the illness of the Herod of Richard Strauss' opera, "Salome."

There are several Herods-we counted at least six. They were related. And not all were titled "kings" although at least three were rulers (Herod the Great, Herod Antipas [Antipater], and Herod Archelaus) and another was briefly an heir to a title (Herod II).

We intended to present the thesis that the Herod portrayed in the Strauss opera, Salome, based on the Wilde play, which was derived from the Moreau painting, may have suffered from chronic lead intoxication. Strauss depicted a Herod (Antipas) who was a despotic ruler persecuting both his Jewish subjects and early Christians. We speculated, reason-

ably we believe, that perhaps lead encephalopathy influenced his behavior and possibly certain historical events. We mistakenly conflated Herod the Great and Herod Antipas, as you point out, and we regret this. As you noted, the Bible also may not have clearly distinguished between these two Herods, and we console ourselves that at least we are in good company. It is not beyond possibility that Strauss, and/or Wilde, too blurred aspects of the identities of these two Herods. Herod the Great died from a mysterious illness that has been the source of speculation; he also might have had chronic lead intoxication, at least in part, as we discussed. However not much seems to be known about the health of Herod Antipas. Our conjecture about his illness in the Strauss Opera, we think, remains plausible.

Yours truly,

Cianna Leatherwood and Richard S. Panush

This Letter is in response to doi:10.1007/s10067-017-3764-9.

Richard S. Panush

panush@usc.edu

1 Department of Medicine, The Keck School of Medicine, University of Southern California and USC+LAC Medical Center, Los Angeles, USA

2 Department of Rheumatology, Brigham and Women's Hospital, Boston, USA

3 Division of Rheumatology, Department of Medicine, The Keck School of Medicine, University of Southern California and USC+LAC Medical Center, Los Angeles, USA 